\title{
SMALL-DIAMETER WHITE MYOTOMAL MUSCLE FIBRES ASSOCIATED WITH GROWTH HYPERPLASIA IN THE CARP (CYPRINUS CARPIO) EXPRESS A DISTINCT MYOSIN HEAVY CHAIN GENE
}

\author{
STEVEN ENNION ${ }^{1}$, LAURENT GAUVRY ${ }^{2}$, PETER BUTTERWORTH ${ }^{3}$ AND GEOFFREY GOLDSPINK ${ }^{1, *}$ \\ ${ }^{1}$ Department of Anatomy and Developmental Biology, Division of Basic Medical Sciences, \\ Royal Free Hospital School of Medicine, University of London, UK, ${ }^{2}$ Laboratoire de Physiologie des Poissons, \\ INRA, Campus de Beaulieu, 35042 Rennes Cedex, France and ${ }^{3}$ Senior Pro-Vice Chancellor's Office, \\ University of Surrey, Guildford, Surrey, UK
}

Accepted 17 March 1995

\begin{abstract}
Summary
A carp myosin heavy chain gene isoform was isolated from a genomic clone, restriction mapped and partially sequenced to reveal the location of various exons. The clone contains a complete gene of approximately $12.0 \mathrm{~kb}$ which is half the size of the corresponding mammalian and avian myosin heavy chain genes. The mRNA transcript of this gene, however, is the same size as mammalian and avian striated muscle myosin heavy chain genes (about 6000 nucleotides), illustrating that the difference in size at the

isoform. Hybridisation analysis could only detect expression of this myosin heavy chain gene in the white muscle of adult carp that had been subjected to an increased environmental temperature. No expression of this gene was detected in carp under 1 year of age. In situ hybridisation demonstrated that expression of this gene is limited to small-diameter white muscle fibres of adult carp, which are thought to be responsible for muscle growth by fibre hyperplasia.
\end{abstract} genomic level is due to shorter introns. A $169 \mathrm{bp} \mathrm{NsiI}$ restriction fragment containing only the $3^{\prime}$ untranslated region of this gene was subcloned and used as an isoformspecific probe to study the expression of this particular
Key words: myosin heavy chain, muscle, carp, Cyprinus carpio, growth.

\section{Introduction}

Growth of skeletal muscle in fish differs from that of mammals and birds in a number of ways. Fish myotomal muscle grows by both fibre hyperplasia and hypertrophy (Greer-Walker, 1983, Stickland, 1983; Weatherley and Gill, 1984) whereas in mammals and birds, increases in the number of fibres stop shortly after embryonic development (Goldspink, 1972). Also, muscle growth rates in fish can vary significantly throughout life depending on factors such as the availability of food or environmental temperature (Loughna and Goldspink, 1985). Furthermore, the muscle of some cyprinid species shows a remarkable adaptability to seasonal temperature changes, with the myofibrillar ATPase activity being 2.8 times greater in cold-acclimated than in warm-acclimated fish (Johnston et al. 1975).

Myosatellite cells are thought to be involved in both hypertrophic and hyperplasic growth of muscle. In hypertrophic growth, they fuse with the existing muscle fibres, supplying additional nuclei, whilst in the hyperplasic growth of carp (Cyprinus carpio), they have been shown to be the source of the new muscle fibres (Koumans et al. 1993a,b). However, there may be species-dependent mechanisms of fibre hyperplasia since studies in the sonic muscle fibres of the toadfish have shown that increases in fibre number occur by fibre splitting (Fine et al. 1993).

Small-diameter fibres (less than $25 \mu \mathrm{m}$ in diameter) present in the white myotomal muscle of carp (Akster, 1983; Rowlerson et al. 1985) are generally assumed to have arisen from myosatellite cells and hence to be involved in the process of fibre hyperplasia. Such fibres have been shown to differ from the larger-diameter fibres both histochemically and immunohistochemically, suggesting that their myosin heavy chain content (MyoHC) is also different (Rowlerson et al. 1985).

Like many other contractile proteins, the MyoHCs are encoded by a highly conserved multigene family (Nguyen $e t$ al. 1982). There are thought to exist at least eight separate striated muscle $\mathrm{MyoHC}$ genes in mammals and as many as 31 in chicken (Robbins et al. 1986). Gerlach et al. (1990) reported that there

*Author for correspondence. 


\section{S. ENNION AND OTHERS}

are up to $28 \mathrm{MyoHC}$ genes present in the carp. Expression of the various isoforms of the $\mathrm{MyoHC}$ gene in mammals has been shown to be under both developmental and tissue-specific control, with specific isoforms expressed in the heart, extraocular muscles, different fibre types and at different stages in development (for a review, see Pette and Staron, 1990).

During the regeneration of damaged mammalian skeletal muscle fibres, myosatellite cells proliferate and fuse either into multi-nucleated myotubes or with the ends of damaged muscle fibres (Hinterberger and Barald, 1990). Recruitment of myosatellite cells in muscle regeneration is known to involve the expression of the embryonic and neonatal isoforms of the myosin heavy chain (Sartore et al. 1982). Whilst histochemical and immunohistochemical studies suggest that the newly formed small-diameter fibres in carp white myotomal muscle contain a different isoform of the myosin heavy chain from that in the larger fibres (Rowlerson et al. 1985), it is not known whether this corresponds to the re-expression of the embryonic/larval isoforms. Isolation and characterisation of the predominant MyoHC isoform expressed in the new small-diameter muscle fibres would provide a valuable tool with which to investigate the mechanisms of fibre hyperplasia in fish growth.

Work in our laboratory has focused on the genes encoding the myosin heavy chain protein in carp. We have previously constructed a carp genomic library and isolated 28 different lambda clones, containing $\mathrm{MyoHC}$ gene sequences (Gerlach et al. 1990). Here we describe the characterisation of one of the carp $\mathrm{MyoHC}$ isogenes isolated. Using the $3^{\prime}$ untranslated region as a probe in hybridisation studies, the expression of this gene is localised to the small muscle fibres of adult growing carp, which are believed to be involved in postembryonic fibre hyperplasia.

\section{Materials and methods}

Isolation of an isoform-specific carp MyoHC probe

The isolation of genomic clones containing carp MyoHC gene sequences has previously been described (Gerlach et al. 1990). DNA sequencing of various restriction fragments from one of these genomic clones, $\lambda \mathrm{FG} 2$, allowed the size of the complete gene to be estimated and various exons to be localised (Fig. 1). Nucleotide sequence data from the $3^{\prime}$ end of this $\mathrm{MyoHC}$ isogene are shown in Fig. 2. It is known that the sarcomeric $\mathrm{MyOHCs}$ isolated from mammalian and avian species show a high degree of sequence homology in their coding region both between and within species (see, for example, Moore et al. 1992). Hence, nucleotide probes for the study of gene expression patterns of individual $\mathrm{MyoHC}$ isoforms within the same species have to be chosen with great care. Large probes which cover the coding region of the gene have been shown to cross-hybridise to a number of $\mathrm{MyoHC}$ isogenes within the same species (Eller et al. 1989) and are therefore of limited use in determining the expression patterns of an individual $\mathrm{MyoHC}$ isogene. However, the $3^{\prime}$ untranslated region ( $3^{\prime}$ UTR) of the gene does show considerable divergence between isogenes, and the 3' UTRs of MyoHC genes from mammals have been used extensively in hybridisation experiments to characterise the expression of the individual isogenes (Loughna et al. 1990; Sutherland et al. 1991; DeNardi et al. 1993).

For the carp FG2 MyoHC isogene, a 169 bp NsiI restriction digest product, containing only the $3^{\prime}$ untranslated region sequence (Fig. 2), was subcloned into $\mathrm{pBS}^{(+)}$vector (Stratagene), named FG2UTR and subsequently used as an isoform-specific probe in Northern and in situ hybridisation to characterise the expression pattern of this particular isoform.

\section{Experimental animals}

Common carp (Cyprinus carpio L.), were obtained from a commercial supplier and kept in 1101 tanks of circulating aerated tap water under a $12 \mathrm{~h}: 12 \mathrm{~h}$ light:dark photoperiod. Twenty-five adult carp of standard body length $(18 \pm 2 \mathrm{~cm})$ and mass $(120 \pm 15 \mathrm{~g})$ were acclimated to $10{ }^{\circ} \mathrm{C}$ for a period of 8 weeks. Five fish were killed at this stage and the water temperature was then raised to $28^{\circ} \mathrm{C}$ over a period of 7 days and at a rate of $3{ }^{\circ} \mathrm{C}$ per day. Once the water temperature had reached $28^{\circ} \mathrm{C}$, four more fish were killed. The water temperature was then maintained at $28^{\circ} \mathrm{C}$ and four fish were killed each week for a further 4 weeks. The fish at $10^{\circ} \mathrm{C}$ were fed to their maximal intake and this rate of feeding was kept

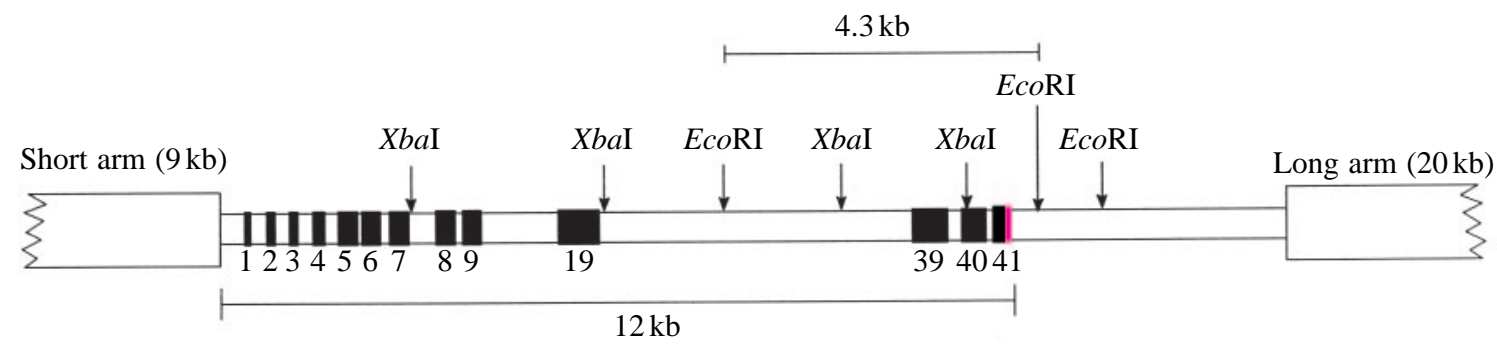

Exons which have been sequenced and located to date

$3^{\prime}$ untranslated region

Fig. 1. Restriction map of the genomic clone $\lambda \mathrm{FG} 2$ indicating the positions (black) of exons that have been sequenced and the sites of action of endonucleases. 
GATATCTGGTGTCATCCTAACAGGAGGAGCAGGCCAACACTCACCTGTCCA $\begin{array}{lllllllllllllll}E & E & Q & A & N & T & H & L & S\end{array}$

101 GGTACAGGAAGGTCCAGCACGAACTGGAGGAGGCTCAGGAGCGCGCTGACA $\begin{array}{lllllllllllllllll}R & Y & R & K & V & Q & H & E & L & E & E & A & Q & E & R & A & D\end{array}$

151 TCGCTGAGTCCCAGGTCAACAAGCTGAGAGCCAAGAGCCGTGATGCTGGGA $\begin{array}{lllllllllllllllll}I & A & E & S & Q & V & N & K & L & R & A & K & S & R & D & A & G\end{array}$

201 AgGTATTATAAAGCTTAATATATGTATACATATATAAATAAGTTTTGGATA

251 AAACAGCACATAACTATAAATTTTTCTTTTCTGTTACTGAAGAGCAAGGAT $S \quad K \quad D$

301 GAAGAATGAAAATGATGCATCAGACCACATCTACAAGCAAGCATATAATAT E E STOP

351 GACTTACTTGTGCTGTCCTTAAATGTCCATTAAATATACATATTCAAGTCA

401 ATCtCTGTTtTGTTATtGTAGTTCAACTGGTAGATAATGGAGACAAAAAT 451 GCCATGATCACAAGGTTCAATTACCAGGGAATGCATGAACTAATAATAAAT

501 GCCTTTAATGAAAAgtAgAtCTAAgtTTGT

Fig. 2. Nucleotide sequence of the $3^{\prime}$ end of the FG2 carp MyoHC gene. The deduced protein sequence of the equivalent to the rat embryonic MyoHC gene (Strehler et al. 1986) exons 40 and 41 is given in the one-letter IUPAC code beneath the nucleotide sequence. A putative polyadenylation signal (AATAAA) and the stop codon are highlighted in pink. The blue text corresponds to the probe FG2UTR used in hybridisation studies. (EMBL accession number Z37108.)

constant throughout the whole experiment. Samples of red and white muscle for RNA extractions and muscle blocks for in situ hybridisation were taken from each fish following killing by decapitation. Muscle samples were taken from the same region of each fish, the region directly below the end of the dorsal fin on the flank of the fish. Carp fry of varying ages and juvenile carp 12 months of age and $5.5-6 \mathrm{~cm}$ in length were also used for RNA extractions.

\section{Hybridisation analysis}

Total RNA was extracted by the method described by Chomczynski and Sacchi (1987). In the case of juvenile and adult carp, $0.25-0.75 \mathrm{~g}$ of tissue was dissected from individual fish and pooled. For carp fry, five whole fish were used for each sample. Electrophoresis of RNA $(30 \mu \mathrm{g})$ was performed in $1.5 \%$ agarose gels made in 3 - $(N$-morpholino $)$ propanesulphonic acid (Mops) buffer $\left(0.02 \mathrm{moll}^{-1}\right.$ Mops, $5 \mathrm{mmoll}^{-1}$ sodium acetate, $1 \mathrm{mmol}^{-1}$ EDTA, $\mathrm{pH} 7.0$ ) with $0.66 \mathrm{moll}^{-1}$ formaldehyde. RNA was transferred to 'Zeta Probe' nylon membrane (Bio-Rad) in $10 \times$ SSC (saline sodium citrate, $1 \times$ concentration; $150 \mathrm{mmol}^{-1} \mathrm{NaCl}, 15 \mathrm{mmoll}^{-1}$ sodium citrate, $\mathrm{pH} 7.0$ ) and fixed by baking at $80^{\circ} \mathrm{C}$ for $2 \mathrm{~h}$. For slot blotting, total RNA $(30 \mu \mathrm{g})$ was applied to 'Zeta Probe' nylon membrane according to the manufacturer's instructions. DNA probes used for hybridisations were labelled by primer extension with $\alpha$ - $\left[{ }^{32} \mathrm{P}\right] \mathrm{dATP}\left(3000 \mathrm{Cimmol}^{-1}\right.$, Amersham International). The FG2UTR probe was specifically primed to give a full-length antisense labelled probe and the FGA101 probe was labelled by random priming (Feinberg and Vogelstein, 1984). Hybridisation and subsequent washes were carried out at $20^{\circ} \mathrm{C}$ below the calculated melting temperature of the probe duplex $\left(64^{\circ} \mathrm{C}\right)$ according to the method of Church and Gilbert (1984). Hybridised probe was detected by exposure of the washed membrane to X-ray film (Du-Pont) at $-70{ }^{\circ} \mathrm{C}$ using an intensifying screen.

\section{In situ hybridisations}

Muscle tissue blocks were fixed in $4 \%$ paraformaldehyde at $4{ }^{\circ} \mathrm{C}$ for $4 \mathrm{~h}$ and then partially dehydrated by $20 \mathrm{~min}$ incubations in three changes of $50 \%$ ethanol and three changes of $70 \%$ ethanol before being processed in an automated waxembedding machine (Tissue TEK III) as in standard histological procedures. Sections at a thickness of $5 \mu \mathrm{m}$ were cut on a sledge microtome, mounted on aminopropyltrimethoxy silane (APTES)-treated slides and dried overnight at $37^{\circ} \mathrm{C}$ before storage at room temperature. Prior to hybridisation, sections were dewaxed by heating to $65^{\circ} \mathrm{C}$ for $10 \mathrm{~min}$ followed by two $10 \mathrm{~min}$ incubations in xylene at room temperature. Sections were then rehydrated through a series of graded alcohols and subjected to pre-hybridisation treatment according to the protocol of Zeller and Rogers (1992). Sense and antisense cRNA probes of FG2UTR were labelled with digoxigenin-11-UTP according to the manufacturer's instructions (Boehringer Mannheim). Probes were heated to $85^{\circ} \mathrm{C}$ for $2 \mathrm{~min}$, rapidly cooled on ice and then diluted 1:10 in hybridisation buffer $(50 \%$ formamide, $0.3 \mathrm{moll}^{-1} \mathrm{NaCl}, 20 \mathrm{mmol}^{-1}$ Tris-HCl, $\mathrm{pH} 8.0,10 \mathrm{mmoll}^{-1}$ sodium phosphate, $\mathrm{pH} 8.0,10 \%$ dextran sulphate, $1 \times$ Denhardt's, $0.5 \mathrm{mg} \mathrm{ml}^{-1}$ yeast tRNA) (Denhardt's consists of $0.02 \%$ bovine serum albumin, $0.02 \%$ polyvinylpyrrolodone, $0.2 \%$ Ficoll) to give a final probe concentration of $5 \mathrm{ng} \mu \mathrm{l}^{-1}$. The probe mixture $(30 \mu \mathrm{l})$ was then added to each section and a siliconised coverslip applied. Sections were incubated for $12 \mathrm{~h}$ in a humid chamber at $42^{\circ} \mathrm{C}$. After hybridisation, slides were dipped into $4 \times$ SSC in order to remove coverslips and the majority of unbound probe. The slides were then washed twice in $2 \times \mathrm{SSC}$ ( $15 \mathrm{~min}$ each time at room temperature) followed by RNAase A treatment at a concentration of $100 \mu \mathrm{g} \mathrm{ml}^{-1}$ in $2 \times \mathrm{SSC}$ for $30 \mathrm{~min}$ at $37^{\circ} \mathrm{C}$. Slides were washed three times in $0.1 \times \mathrm{SSC}$ (twice for $20 \mathrm{~min}$ at $42^{\circ} \mathrm{C}$ and once for $10 \mathrm{~min}$ at room temperature). For detection of hybridised probe, alkaline-phosphatase-conjugated antidigoxygenin antibody (1:500 dilution in Boehringer Mannheim buffer 2) with NBT/X-phosphate precipitation was used according to the manufacturer's instructions (Boehringer Mannheim). Unbound antibody was removed with three $5 \mathrm{~min}$ washes in $100 \mathrm{mmoll}^{-1}$ Tris-HCl (pH 7.4) with $150 \mathrm{mmoll}^{-1}$ $\mathrm{NaCl}$ at room temperature. The colour precipitation reaction was left for $16 \mathrm{~h}$ and the sections were dehydrated through graded alcohols, cleared in xylene and mounted with DPX. 
1606 S. ENNION AND OTHERS

\section{Results}

The carp MyoHC gene FG2 is approximately half the size of mammalian MyoHC genes

The genomic clone $\lambda \mathrm{FG} 2$ was shown to contain a full $\mathrm{MyoHC}$ gene from $900 \mathrm{bp} \mathrm{5^{ \prime }}$ of the translational start site through to the stop codon and $3^{\prime}$ untranslated region (Fig. 1). Characterisation of the $5^{\prime}$ regulatory region of this gene is currently in progress and will be described elsewhere. The nucleotide sequence of exons 1-7 of the gene is deposited in the EMBL sequence data base under the accession number Z37999 whilst the $3^{\prime}$ end nucleotide sequence (Fig. 2) is under the accession number Z37108.

The size of the complete gene is $12 \mathrm{~kb}$ and this is approximately half the size of the complete mammalian and chicken striated muscle $\mathrm{MyoHC}$ genomic sequences published to date, which range from 22.8 to $24.6 \mathrm{~kb}$ (Jaenicke et al. 1990; Strehler et al. 1986; Molina et al. 1987; Matsuoka et al. 1991). This difference in size at the genomic level is due to the size of the introns. The 13 exons of the gene that have been sequenced to date are all of similar size and show high sequence identity to the equivalent exons in the mammalian and chicken $\mathrm{MyoHC}$ genes. The introns, however, are consistently shorter. For further evidence supporting this theory of shorter introns, see Fig. 5, where Northern blot analysis shows that the corresponding mRNA transcript is approximately $6 \mathrm{~kb}$ in length, the same size as the mammalian and chicken striated muscle $M y O H C$ mRNAs.

Of the four complete striated muscle $\mathrm{MyoHC}$ genomic sequences published to date, only one, the rat embryonic MyoHC (Strehler et al. 1986), has a final exon coding for five amino acids. In the other three complete sequences, the human $\beta$ cardiac (Jaenicke et al. 1990), the chicken embryonic (Molina et al. 1987) and the human $\alpha$ cardiac (Matsuoka et al. 1991), these five amino acids are at the end of the previous exon. The carp FG2 MyoHC gene is similar to the rat embryonic $\mathrm{MyoHC}$ in that these five amino acids are also located on a separate exon. It is difficult to postulate the significance of the location of this final exon without additional information about the $3^{\prime}$ exon structure of $\mathrm{MyoHC}$ genes from a divergent range of species. However, the location of this exon may reflect the evolution of the different MyoHC isoforms from common ancestral genes.

\section{Specificity of the carp FG2 MyoHC 3' UTR probe}

In order to verify that the FG2UTR probe does not crosshybridise with other members of the carp $\mathrm{MyoHC}$ gene family, it was necessary to perform hybridisation analysis of carp genomic DNA digested with restriction endonuclease (Fig. 3). As would be expected from the restriction map presented in Fig. 1, the FG2UTR probe hybridises to a single $4.3 \mathrm{~kb} E c o$ RI fragment. Single genomic restriction fragments of $8.5 \mathrm{~kb}$ $(X b a \mathrm{I})$ and $3.7 \mathrm{~kb}(P s t \mathrm{I})$ also hybridised with the FG2UTR probe, further demonstrating that the FG2UTR probe is indeed isogene-specific.

Sequence comparison of the $3^{\prime}$ coding region of the FG2 $\mathrm{MyoHC}$ isogene with the equivalent regions in other published

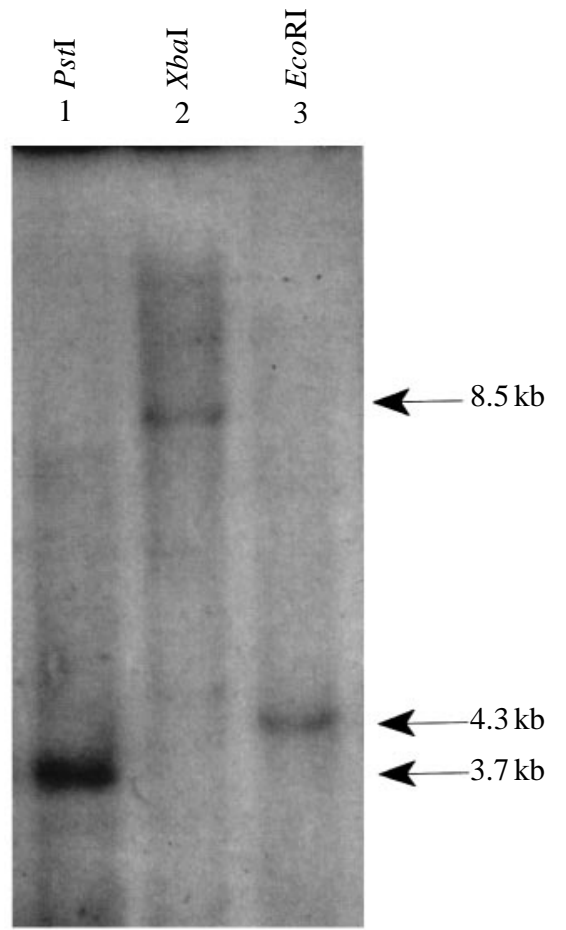

Fig. 3. Genomic Southern hybridisation. Genomic DNA was extracted from adult carp liver as previously described (Gerlach et al. 1990). The restriction endonucleases PstI, XbaI and EcoRI (Boehringer Mannheim) were then used to digest $10 \mu \mathrm{g}$ samples of genomic DNA to completion. The digested DNA was separated by agarose gel electrophoresis (1\% gel in TBE buffer), transferred to 'Zeta Probe' nylon membrane and hybridised with the FG2UTR probe which had been labelled by primer extension with $\alpha-\left[{ }^{32} \mathrm{P}\right] \mathrm{dATP}$. Hybridisation and washing conditions were according to the method of Church and Gilbert (1984) at a temperature of $60^{\circ} \mathrm{C}$. With each restriction enzyme, a single hybridising band was observed, confirming the specificity of the FG2UTR probe.

MyoHC genes shows a high degree of sequence homology (Fig. 4). The 3' UTR of the FG2 MyoHC isogene, however, does not show sequence homology with any published $\mathrm{MyOHC}$ sequence. With the mammalian $\mathrm{MyoHC}$ genes, it has become apparent that sequence homology exists within the $3^{\prime}$ UTRs of equivalent isoforms in different species. The $3^{\prime}$ UTR of the rat fast 2A MyoHC gene (DeNardi et al. 1993) is highly homologous to the 3' UTR of the human fast 2A MyoHC gene (Ennion et al. 1995). Since the 3' UTR of the carp FG2 MyoHC isogene does not show any homology with any other published $\mathrm{MyoHC}$ isogene, it is not possible to consider it in the context of the nomenclature of myosin heavy chain genes adopted for mammals.

\section{The expression of the FG2 MyoHC gene is restricted to the white muscle of adult carp acclimated to a warm temperature}

The use of the isogene-specific FG2 3' UTR probe in Northern hybridisation analysis demonstrated the dynamic nature of $\mathrm{MyoHC}$ isogene expression in carp subjected to changes in environmental temperature. Expression of the FG2 
Fig. 4. Comparison of the $3^{\prime}$ coding region of FG2 with other $\mathrm{MyoHC}$ genes. Amino acid sequences are given in the one-letter IUPAC code. MyoHC genes with which FG2 was compared and associated accession numbers are as follows: (1) human embryonic (X13988); (2) rat embryonic (X04267); (3) human $\beta$ cardiac (M30605); (4) baboon $\beta$

FG2

1. HUMANEMB

2. RATEMB

3. $\operatorname{HUMAN} \beta$

4. $\mathrm{BABOON} \beta$

5. RAT $\beta$

6. $\operatorname{HUMAN} \alpha$

7. RAT $\alpha$

8. RABBIT $\alpha$

9. RATEOM

\begin{abstract}
EEQANTHLSRYRKVQHELEEAQERADIAESQVNKLRAKSRD_AGK__SKDEE DEQANAHLTKFRKAQHELEEAEERAD IAESQVNKLRAKTRDFTSSRMVVHESEE DEQANVHLTKFRKAQHELEEAEERADIAESQVNKLRAKTRDFTSSRMVVHESEE EEQANTNLSKFRKVQHELDEAEERADIAESQVNKLRAKSRDIGTK__GLNEE EEQANTNLSKFRKVQHELDEAEERADIAESQVNKLRAKSRDIGTK__GLNEE EEQANTNLSKFRKVQHELDEAEERADIAESQVNKLRVKSRDIGAK_ GLNEE EERANTNLSKFRKVQHELDEAEERADIAESQVNKLRAKSRDIGAK_KMDEE EEQANTNLSKFRKVQHELDEAEERADIAESQVNKLRAKSRDIGAK_ QKMHDEE EEQANTNLSKFRKVQHELDEAEERADIAESQVNKLRAKSRDIGAK_QKMHDEE EEQANTQLSKFRKVQHELEEAEERAD IAESQVNKLRFKSRD____ KMEE

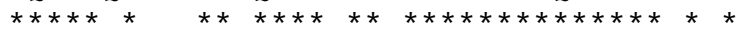
cardiac (M19932); (5) rat $\beta$ cardiac (X15939); (6) human $\alpha$ cardiac (D00943); (7) rat $\alpha$ cardiac (X15938); (8) rabbit $\alpha$ cardiac (K011867); (9) rat extrocular isoform (M28654). An asterisk indicates amino acid residues conserved in all the sequences.

MyoHC isogene was only detected in adult white muscle of carp that had been exposed to a warm $\left(28^{\circ} \mathrm{C}\right)$ environmental temperature. No expression was observed in white muscle from carp at $10^{\circ} \mathrm{C}$ (Fig. 5, lanes 3 and 4), or up to 1 week at $28^{\circ} \mathrm{C}$ (lane 5). Strong expression of the FG2 MyoHC isoform was detected through weeks 2,3 and 4 at $28^{\circ} \mathrm{C}$ and a slightly weaker expression by week 5 . To correlate the expression of the FG2 $\mathrm{MyoHC}$ isogene with levels of muscle tissue mRNA,
Fig. 5. Northern blot analysis. Total RNA $(30 \mu \mathrm{g})$ from carp was separated by electrophoresis, transferred to nylon membrane and hybridised sequentially with the carp $\mathrm{MyoHC}$ gene probe FG2UTR and the carp actin probe FGA101 (Gerlach et al. 1990). Lanes contain RNA from the pooled muscle samples of a number of fish as indicated below. (A) The membrane was hybridised under high-stringency conditions with the probe FG2UTR and the blot exposed to X-ray film at $-70{ }^{\circ} \mathrm{C}$ for 1 week. Subsequently, the membrane was stripped and reprobed under highstringency conditions with the carp actin probe FGA101. The blot was exposed to X-ray film at $-70{ }^{\circ} \mathrm{C}$ for $72 \mathrm{~h}$ and superimposed on the autoradiograph of the FG2UTR hybridisation. (B) Ethidium bromide staining of the original RNA agarose gel. Lanes are as follows. (1) Red muscle from four carp acclimated to $28^{\circ} \mathrm{C}$ for 5 weeks. (2) Carp spleen. (3) White muscle from three carp acclimated to $10^{\circ} \mathrm{C}$ for 5 weeks. (4) White muscle from two carp acclimated to $10^{\circ} \mathrm{C}$ for 5 weeks. (5) White muscle from four carp acclimated to $28^{\circ} \mathrm{C}$ for 1 week. (6) Blank lane, no RNA. (7) White muscle from four carp acclimated to $28^{\circ} \mathrm{C}$ for 2 weeks. (8) White muscle from two carp acclimated to $28^{\circ} \mathrm{C}$ for 3 weeks. (9) White muscle from two carp acclimated to $28^{\circ} \mathrm{C}$ for 3 weeks. (10) White muscle from four carp acclimated to $28^{\circ} \mathrm{C}$ for 4 weeks. (11) White muscle from two carp acclimated to $28^{\circ} \mathrm{C}$ for 5 weeks. (12) White muscle from two carp acclimated to $28^{\circ} \mathrm{C}$ for 5 weeks. (13) White muscle from three juvenile (1-year-old) carp. (14) Five whole 60-day-old carp fry, $1.2 \mathrm{~cm}$ long, acclimated to $28^{\circ} \mathrm{C}$ for 2 weeks. (15) Five whole 60-day-old carp fry, $1.2 \mathrm{~cm}$ long, acclimated to $15^{\circ} \mathrm{C}$ for 2 weeks. (16) Unhatched carp eggs $24 \mathrm{~h}$ after fertilisation.

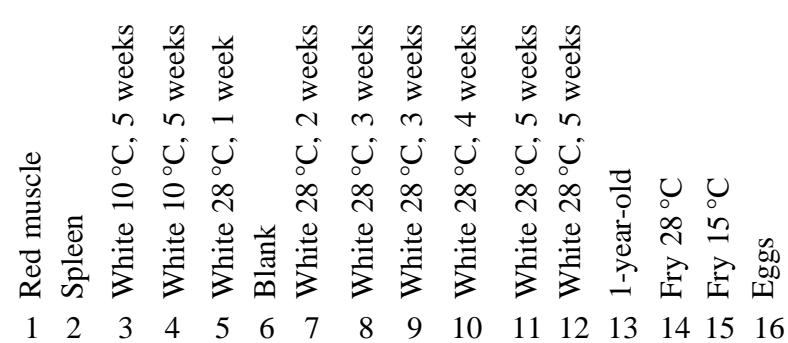

A

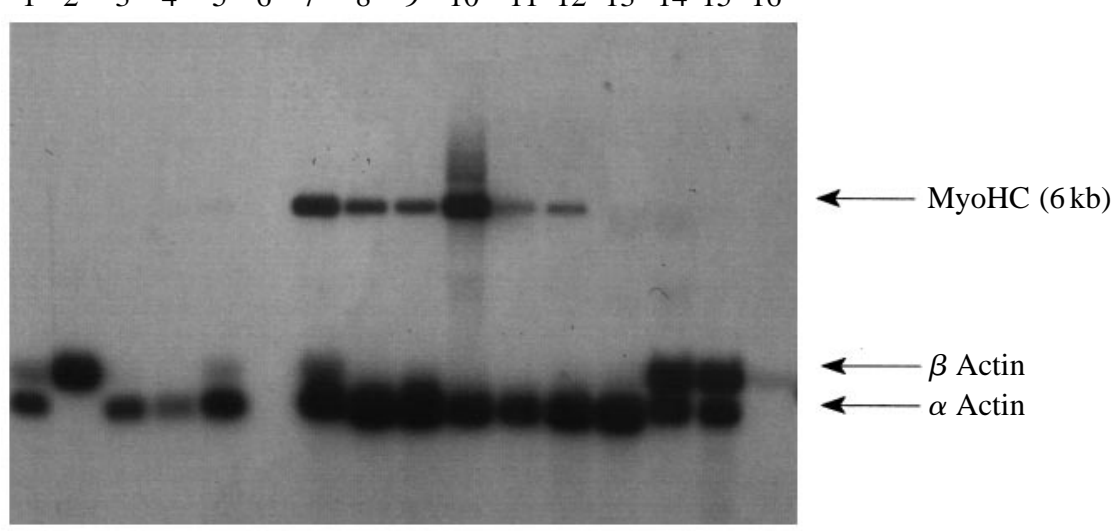

B

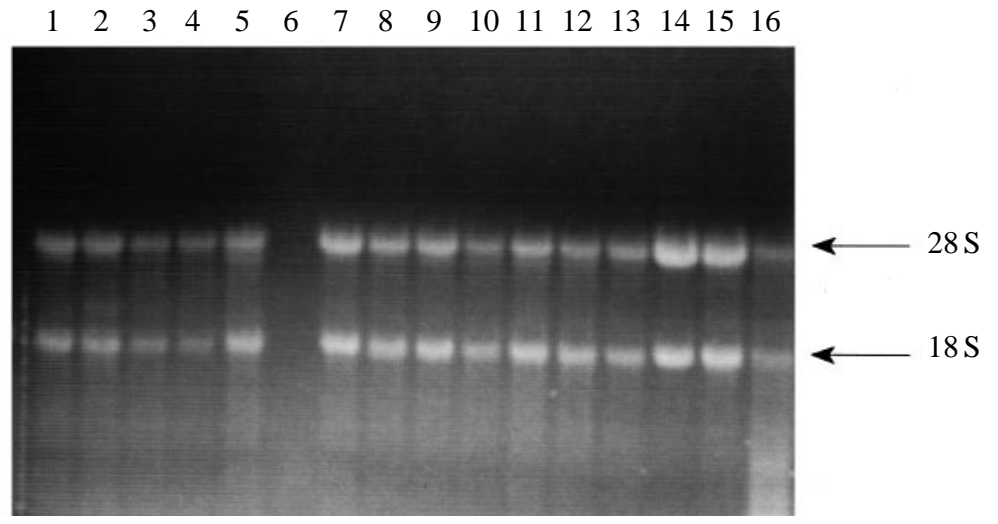




\section{S. ENNION AND OTHERS}

the membranes were stripped and rehybridised with FGA101 (Gerlach et al. 1990), a carp actin probe that hybridises with both isoforms of actin ( $\alpha$ and $\beta$ ). When compared with the level of actin expression in carp which had been maintained at $28^{\circ} \mathrm{C}$ for more than 1 week, the level of actin mRNA expression in carp sampled at $10^{\circ} \mathrm{C}$ and in the carp maintained at $28^{\circ} \mathrm{C}$ for 1 week was lower. However, the level of actin expression did not correlate with the amount of FG2 $\mathrm{MyoHC}$ mRNA expression in carp that had been at $28^{\circ} \mathrm{C}$ for more than 1 week (Fig. 5, lanes 7-12). Expression of the FG2 MyoHC isoform was not detected in carp red muscle, 1-year-old carp, carp fry of various ages or unhatched carp eggs (Figs 5A, 6). Hybridisation of the carp actin probe FGA101 and ethidium bromide staining of the RNA gel (Fig. 5B) confirm the integrity of the RNA samples.

\section{Expression of the FG2 MyoHC isoform is localised to small- diameter white muscle fibres}

In situ hybridisation experiments using sense and antisense labelled FG2UTR probes revealed that the FG2 MyoHC isoform is expressed in a specific population of white muscle fibres in fish that had been acclimated to a warm temperature (Fig. 7). The fibres shown to be expressing the FG2 MyoHC isoform in the warm-acclimated carp were less than $25 \mu \mathrm{m}$ in diameter (Fig. 7B,D). These small-diameter fibres were also present in the cold-acclimated fish (Fig. 7E), but in these fish they were far fewer in number and no expression of the FG2 MyoHC isoform could be detected by either in situ hybridisation or Northern blot analysis. This suggests that the FG2 MyoHC isoform is only expressed in adult carp when they are in a growth phase.

\section{Discussion}

The results obtained in this study by in situ hybridisation with the FG2UTR probe (Fig. 7) show that the small white muscle fibres express a $\mathrm{MyoHC}$ gene (FG2) that is not expressed in the red muscle fibres or in the large fibres of the white muscle. This and the fact that a clear boundary was always observed between the fibres expressing the FG2 isoform and surrounding fibres is supportive to the theory that, in carp, the myosatellite cells are the source of the new small-diameter muscle fibres. Recently, Rowlerson et al. (1995) have shown that the small-diameter white muscle fibres of the gilthead seabream Sparus aurata have a high mitotic activity, which also indicates that their origin is from myosatellite cells. The carp FG2 MyoHC gene is apparently expressed transiently when the small fibres are induced to grow. However, it cannot be considered as an embryonic or neonatal MyoHC equivalent isoform since hybridisation analysis (Figs 5,6) showed that it is not expressed in juvenile carp, carp fry and unhatched carp eggs.

Mosaic white muscle containing both large- and smalldiameter fibres has also been described in the sea bass Dicentrarchus labrax (Scapolo et al. 1988). In this species, the small-diameter fibres in the mosaic white muscle of the larvae have different histochemical and immunohistochemical properties from the small-diameter fibres present in adult fish. Scapolo and coworkers interpreted these results as an indication of different mechanisms of fibre hyperplasia in adult and young fish. Therefore, small fibres present in adult carp arising from myosatellite cells would not necessarily show expression of embryonic or neonatal MyoHC equivalents.

As it is likely that the source of the new muscle fibres expressing the FG2 gene is the myosatellite cells (Koumans et al. 1993a,b), then the pattern of MyoHC isoform expression during myosatellite cell recruitment in carp muscle hyperplasic growth would appear to differ from that in myosatellite cell
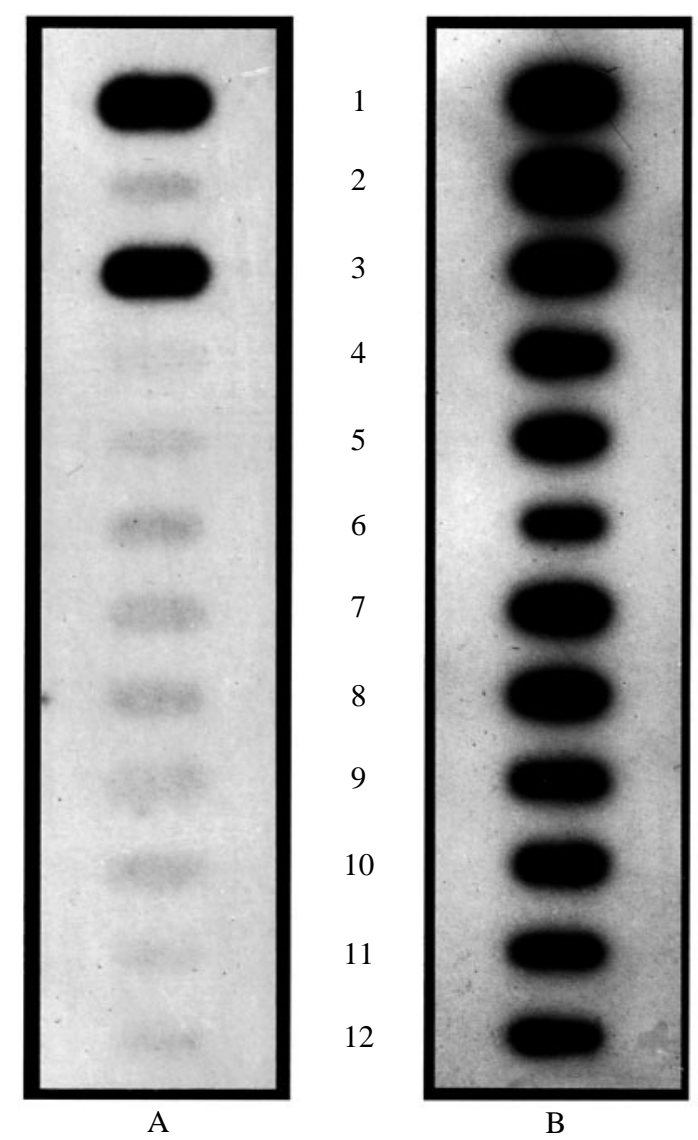

Fig. 6. Slot blot hybridisation of carp total RNA to the probes FG2UTR and FGA101. The RNA loaded on each slot $(30 \mu \mathrm{g})$ was extracted from the pooled muscle samples of three fish. The membrane was hybridised under high-stringency conditions with FG2UTR and exposed to X-ray film for $24 \mathrm{~h}$ (A). Subsequently, the membrane was stripped of bound probe and rehybridised with the carp actin probe FGA101 (B, exposure $24 \mathrm{~h}$ ). Lanes are as follows. (1) Deep white muscle from adult carp (3 years old, $16.2-17.5 \mathrm{~cm}$ in length) acclimated to $28^{\circ} \mathrm{C}$ for 5 weeks. (2) Red muscle from adult carp (same fish as in slot 1). (3) Superficial white muscle from adult carp (same fish as in slot 1). (4) Adult carp spleen. (5) Whole heart from adult carp. (6) 20-day-old carp fry (five whole fish). (7) 12-dayold carp fry (five whole fish). (8) 8-day-old carp fry (five whole fish). (9) 4-day-old carp fry (five whole fish). (10) 2-day-old carp fry (five whole fish). (11) Red muscle from adult carp (3 years old, $16.0-18.0 \mathrm{~cm}$ in length) acclimated to $10^{\circ} \mathrm{C}$ for 5 weeks. (12) White muscle from adult carp (same fish as in slot 11). 

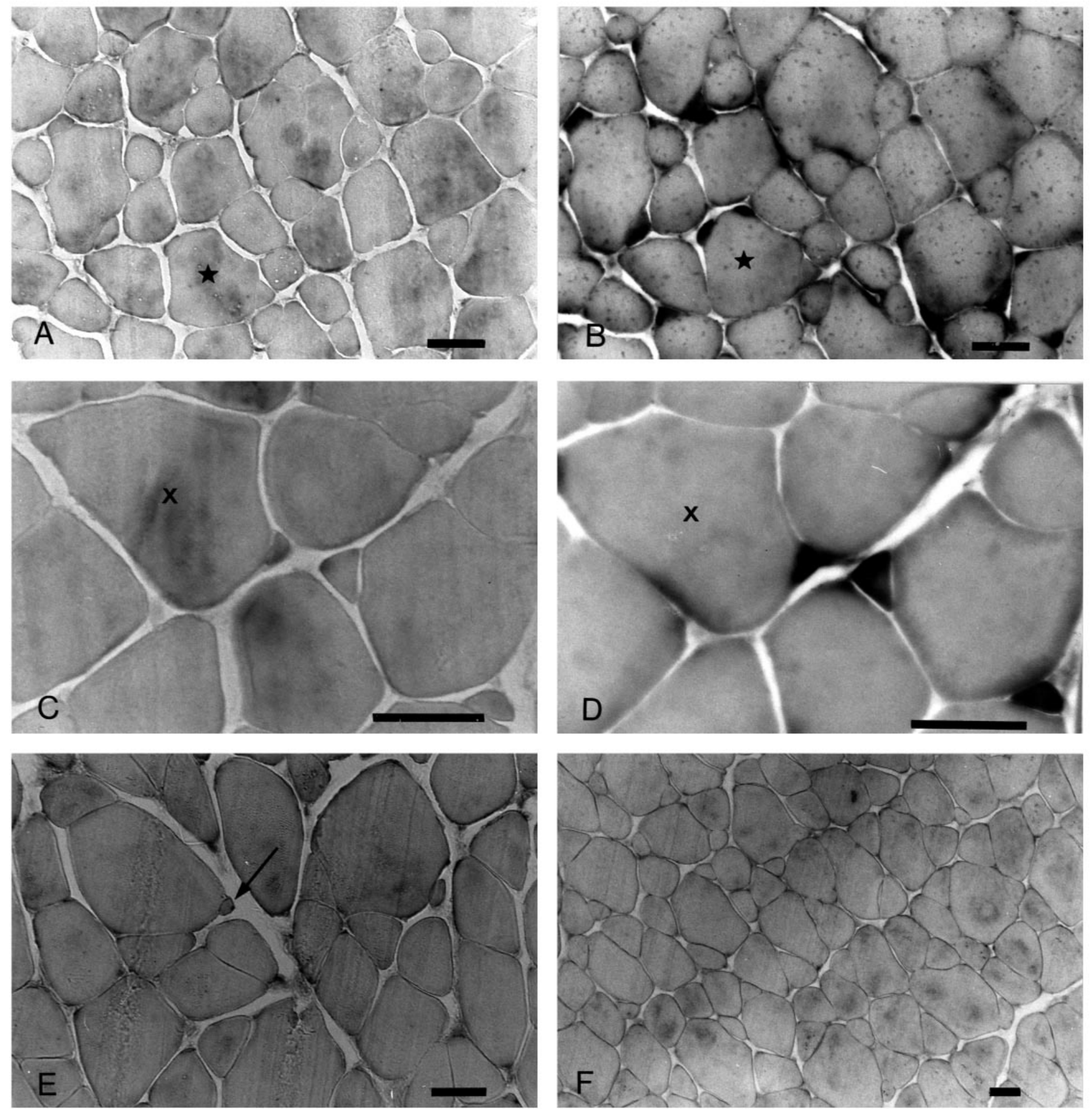

Fig. 7. In situ hybridisation using the FG2UTR probe on muscle sections from warm- and cold-acclimated carp. A and B show transverse sections of white muscle from adult carp exposed to $28^{\circ} \mathrm{C}$ for 2 weeks. The star $(\star)$ indicates the same muscle fibre in serial sections. $\mathrm{C}$ and $\mathrm{D}$ show transverse sections of white muscle from adult carp exposed to $28^{\circ} \mathrm{C}$ for 5 weeks. The cross $(\times)$ indicates the same muscle fibre in serial sections. A and C correspond to the sense labelled FG2UTR probe. B and D correspond to the antisense labelled FG2UTR probe. E and $\mathrm{F}$ show transverse sections of white muscle fibres from adult carp kept at $10^{\circ} \mathrm{C}$ for 5 weeks. Both $\mathrm{E}$ and $\mathrm{F}$ correspond to the antisense labelled FG2UTR probe. Scale bars, $50 \mu \mathrm{m}$.

recruitment during muscle regeneration in mammals, since in mammals the embryonic and neonatal MyoHC isoforms are reexpressed (Sartore et al. 1982). Thus, the carp FG2 MyoHC gene is best regarded as a 'growth isoform gene' for which a mammalian equivalent has not been described.
That there is a $M y o H C$ gene which is expressed during the growth phase of the small-diameter white muscle fibres in carp and that this gene does not appear to be expressed at any other time are interesting observations highlighting the differences between muscle growth in fish and in other species. The 


\section{S. ENNION AND OTHERS}

requirement for the expression of a growth-related isoform in fish, or indeed for the expression of embryonic/neonatal MyoHC isoforms during early muscle development, is unresolved. According to the so-called 'functional' hypothesis (Gros and Buckingham, 1987), the differential expression of various MyoHC isoforms throughout development and in the different fibre types of the adult are consequences of various functional demands on the molecule dictating the evolution of a multigene family by selective pressure. Such functional demands may possibly reside in the $\mathrm{S} 1$ region of the molecule, where differences in primary structure could affect its actin binding properties and ATPase activity. Alternatively, the functional demands that dictate evolutionary pressure for multiple MyoHC isoforms may reside in the light meromyosin (LMM) region, where differences in structure may be required for the correct construction of the thick filament in particular cellular environments (Taylor and Bandman, 1989). Thus, if the expression of the carp FG2 MyoHC isoform in the smalldiameter newly developing white muscle fibres is driven by functional demands, then one would hypothesise that properties in the LMM that facilitate the correct formation of thick filaments could be important since it is difficult to envisage changes in ATPase activity in such a population of fibres affecting the locomotory ability of the fish.

An alternative to the 'functional' hypothesis is that isoform polymorphism confers regulatory advantages at the level of gene expression rather than controlling changes in protein function. That is to say, although the MyoHC isoforms themselves may be very similar in their functional properties, they differ significantly in the regulatory regions of their genes. The cellular environment is probably sufficiently different in the newly developing or growing muscle fibres to necessitate the existence of isogenes that differ in their regulatory regions. Thus, it may be necessary to build the initial myofibrillar infrastructure using a MyoHC isoform that is transiently but strongly expressed. Thereafter, this MyoHC isoform can be readily exchanged for the molecules of the adult type genes. A study of the promoter region of the different $\mathrm{MyoHC}$ isogenes should shed light on the developmental expression of such isoforms of the $\mathrm{MyoHC}$ gene family.

Fundamental biological processes such as growth and adaptation can often be studied better in non-mammalian species such as fish. Certainly the use of gene probes to determine the switches in gene expression that initiate the phenotypic changes will enable the cellular mechanisms to be elucidated at a fundamental level.

We are grateful to Mr T. Gysbers for his preparation of photographic material. This work was supported by grants to Professors Goldspink and Butterworth from the SERC (S.E.) and the NERC (L.G.).

\section{References}

AKster, H. A. (1983). A comparative study of fibre type characteristics and terminal innervation in head and axial muscle of the carp (Cyprinus carpio L.): a histochemical and electronmicroscopial study. Neth. J. Zool. 33, 164-188.

Chomczynski, P. AND SACCHI, N. (1987). Single-step method of RNA isolation by acid guanidinium thiocyanate-phenol-chloroform extraction. Analyt. Biochem. 162, 156-159.

Church, G. M. And Gilbert, W. (1984). Genomic sequencing. Proc. natn. Acad. Sci. U.S.A. 81, 1991-1995.

DeNardi, C., Ausoni, S., Moretti, P., Gorza, L., Velleca, M., Buckingham, M. And Schiaffino, S. (1993). Type-2x-myosin heavy chain is coded by a muscle fiber type-specific and developmentally regulated gene. J. Cell Biol. 123, 823-835.

Eller, M. Stedman, H. H., Sylvester, J. E., Fertels, S. H., Wu, Q. L., Raychowdhury, M. K., Rubinstein, N. A., Kelly, A. M. AND SARKAR, S. (1989). Human embryonic myosin heavy chain cDNA. Interspecies sequence conservation of the myosin rod, chromosomal locus and isoform specific transcription of the gene. FEBS Lett. 256, 21-28.

Ennion, S., Sant'ana Pereira, J., Sargeant, A. J., Young, A. And GoldsPINK, G. (1995). Characterisation of human skeletal muscle fibres according to the myosin heavy chains they express. J. Muscle Res. Cell Motil. 16, 35-43.

Feinberg, A. P. And Vogelstein, B. (1984). Addenum: A technique for radiolabelling DNA restriction endonuclease fragments to high specific activity. Analyt. Biochem. 137, 266-267.

Fine, M. L., Bernard, B. AND Harris, T. M. (1993). Functional morphology of toadfish sonic muscle fibers - relationship to possible fiber division Can. J. Zool. 71, 2262-2274.

Gerlach, G. F., Turay, L., Malik, K. T., Lida, J., Scutt, A. AND GoldsPINK, G. (1990). Mechanisms of temperature acclimation in the carp: a molecular biology approach. Am. J. Physiol. 259, R237-R244.

GolDSPINK, G. (1972). Postembryonic growth and differentiation of striated skeletal muscle. In The Structure and Function of Muscle (ed. G. H. Bourne), pp. 179-236. New York: Academic Press.

GREER-WALKER, M. (1983). Growth and development of skeletal muscle fibres in the cod. J. Cons. int. Explor. Mer 33, 228-244.

Gros, F. And Buckingham, M. E. (1987). Polymorphism of contractile proteins. Biopolymers 26, S177-S192.

Hinterberger, T. J. ANd Barald, K. F. (1990). Fusion between myoblasts and adult muscle fibers promotes remodelling of fibers into myotubes in vitro. Development 109, 139-148.

Jaenicke, T., Diederich, K. W., HaAs, W., Schleich, J., Lichter, P., PFordt, M. AND Vosberg, H. P. (1990). The complete sequence of the human beta-myosin heavy chain gene and a comparative analysis of its product. Genomics 8, 194-206.

Johnston, I. A., DAvison, W. AND GoldspinK, G. (1975). Adaptations in $\mathrm{Mg}^{++}$-activated myofibrillar ATPase induced by temperature acclimation. FEBS Lett. 50, 293-295.

Koumans, J. T. M., Akster, H. A., Booms, G. H. R. And Osse, J. W. M. (1993a). Growth of carp (Cyprinus carpio) white axial muscle: hyperplasia and hypertrophy in relation to the myonucleus/sarcoplasm ratio and the occurrence of different subclasses of myogenic cells. J. Fish Biol. 43, 69-80.

Koumans, J. T. M., Akster, H. A., Booms, R. G. H. And Osse, J. W. M. (1993b). Influence of fish size on proliferation of cultured myosatellite cells of white axial muscle of carp (Cyprinus carpio L.). Differentiation 53, 1-6.

Loughna, P. T. AND GoldsPink, G. (1985). Muscle protein synthesis rates during temperature acclimation in a eurythermal (Cyprinus carpio) and a stenothermal (Salmo gairdneri) species of teleost. $J$. exp. Biol. 118, 267-276. 
Loughna, P. T., Izumo, S., Goldspink, G. And NADAl-Ginard, B. (1990). Disuse and passive stretch cause rapid alterations in expression of developmental and adult contractile protein genes in skeletal muscle. Development 109, 217-223.

Matsuoka, R., Beisel, K. W., Furutani, M., Arai, S. and Takao, A. (1991). Complete sequence of human cardiac alpha-myosin heavy chain gene and amino acid comparison to other myosins based on structural and functional differences. Am. J. med. Genetics 41, 537-547.

Molina, M. I., Kropp, K. E., Gulick, J. And Robbins, J. (1987). The sequence of an embryonic myosin heavy chain gene and isolation of its corresponding cDNA. J. biol. Chem. 262, 6478-6488.

Moore, L. A., Tidyman, W. E., Arrizubieta, M. J. And Bandman, E. (1992). Gene conversions within the skeletal myosin multigene family. J. molec. Biol. 223, 383-387.

Nguyen, H. T., Gubits, R. M., Wydro, R. M. AND NADAL-GinARD, B. (1982). Sarcomeric myosin heavy chain is coded by a highly conserved multigene family. Proc. natn. Acad. Sci. U.S.A. 79, 5230-5234.

Pette, D. AND Staron, R. S. (1990). Cellular and molecular diversities of mammalian skeletal muscle fibers. Rev. Physiol. Biochem. Pharmac. 116, 1-76.

RobBins, J., Horan, T., Gulick, J. AND KropP, K. (1986). The chicken myosin heavy chain family. J. biol. Chem. 261, 6606-6612.

Rowlerson, A., Mascarello, F., Radaelli, G. and Veggeti, A. (1995). Differentiation and growth of muscle in the fish Sparus aurata (L.). II. Hyperplastic and hypertrophic growth of lateral muscle from hatching to adult. J. Muscle Res. Cell Motil. (in press).

Rowlerson, A., Scapolo, P. A., Mascarello, F., Carpene, E. AND VEGGETI, A. (1985). Comparative study of myosins present in the lateral muscle of some fish: species variations in myosin isoforms and their distribution in red, pink and white muscle. J. Muscle Res. Cell Motil. 6, 601-640.

Sartore, S., Gorza, L. And Schiaffino, S. (1982). Fetal myosin heavy chains in regenerating muscle. Nature 298, 294-296.

Scapolo, P. A., Veggetti, A., Mascarello, F. and Romanello, M. G. (1988). Developmental transitions in myosin isoforms and organisation of the lateral muscle in the teleost Dicentrarchus labrax (L.). Anat. Embryol. 178, 287-295.

STICKLAND, N. C. (1983). Growth and development of muscle fibres in the rainbow trout (Salmo gairdneri). J. Anat. 137, 323-333.

Strehler, E. E., Strehler-Page, M. A., Perriard, J. C., Periasamy, M. AND NADAL-GinARD, B. (1986). Complete nucleotide and encoded amino acid sequence of a mammalian myosin heavy chain gene. Evidence against intron-dependent evolution of the rod. $J$. molec. Biol. 190, 291-317.

Sutherland, C. J., Elsom, V. L., Gordon, M. L., Dunwoodie, S. L. AND HaRdeman, E. C. (1991). Coordination of skeletal muscle gene expression occurs late in mammalian development. Devl Biol. 146, 167-178.

TAYLOR, L. D. AND BANDMAN, E. (1989). Distribution of fast myosin heavy chain isoforms in thick filaments of developing chicken pectoral muscle. J. Cell Biol. 108, 533-542.

Weatherley, A. H. AND GiLl, H. S. (1984). Growth dynamics of white myotomal muscle fibres in the bluntnose minnow (Pimephales notatus Rafinesque) and comparison with rainbow trout (Salmo gairdneri Richardson). J. Fish Biol. 25, 13-24.

Zeller, R. AND Rogers, M. (1992). In situ hybridisation and immunohistochemistry. In Current Protocols in Molecular Biology (ed. F. M. Ausubel, R. Brent, R. E. Kingston, D. D. Moore, J. G. Seidman, J. A. Smith and K. Struhl), pp. 14.0.1-14.6.13. New York: John Wiley and Sons. 